DJS Vol. 44(1) (2022)- pp. 28-48 ISSN: 1012-5965

Delta Journal of Science

Available online at https://djs.journals.ekb.eg/

GEOLOGY

\title{
Seismic Interpretations and Petrophysical Evaluation of the Two Main Reservoirs in Abu Madi Formation, Level-2 and Level-3, Nidoco Field, Nile Delta, Egypt
}

\section{Hassan Hassan El-Kadi ${ }^{1}$, Mohamed Fathi Mohamed Ali ${ }^{1}$, and Mustafa Omar ${ }^{2 *}$}

${ }^{1}$ Geology Department, Faculty of Science, Al Azhar University, Nasr City, Cairo, Egypt.

${ }^{2}$ Belayim Petroleum Company, Nasr City, Cairo, Egypt.

Corresponding author: Mustafa Omar e-mail: geo_mustafa_z14@yahoo.com

Received: 18/11/2021 Accepted : 22/12/2021

\section{KEY WORDS}

Geological

Mapping; Well-

logs; Petrophysical

Evaluation; $\mathrm{Abu}$

Madi Fm; Nidoco

Field; Nile Delta

\section{ABSTRACT}

Nidoco Field is a large gas field located at the central part of the Nile Delta, along the coast of the Mediterranean Sea. The field stopped production in 2012, due to high water production. Therefore, this work has started to find new opportunities for exploration and production. According to the result of work, new successful wells have been drilled, with huge added reserves in 2015. This work deals mainly with a comprehensive interpretation of the available seismic and well-log data in Nidoco Field. The seismic interpretation was started by generating synthetic seismograms for the studied wells, to link between well-log and seismic data. After good seismic to well tie, detailed seismic interpretation and accordingly geo-seismic cross sections were generated. In addition, complete petrophysical evaluation of the studied wells were studied vertically in the form of litho-saturation cross-plots inferred from the computer processed interpretation (CPI). From these seismic interpretations and petrophysical evaluations, a series of time, velocity, depth, seismic amplitudes, shale content, effective porosity, hydrocarbon saturation and reservoir thickness maps were constructed for the main two reservoirs (Level-2 and Level-3), to have a complete understanding of their geologic properties. The integration of all mentioned data have been allowed the detection of best locations to be drilled and huge gas discoveries have been achieved and production started again from Nidoco Field. Beside that, other new locations are recommended to be drilled, as exploratory and development wells, to produce more hydrocarbons from the study area, which still showing high hydrocarbon potentialities. 


\section{Introduction}

In Egypt, the Nile Delta region has been considered as one of the most important gas provinces, as its sedimentary succession seems to hide a high gas potentiality (Dolson et al., 2005). The studied area, Nidoco field, is located in central Nile Delta, in the Abu Madi West Development Lease, operated by Petrobel. The Abu Madi West Development Lease was defined around Nidoco field. The field was discovered in 1993, through N-6 well. In 2011, the last well in the field (N-E-1 well) was drilled, aimed to raise the decreasing production inside the development lease. In December 2012, the production was stopped, due to the high water production. Intensive work has been done and the results showed that, the remaining-potential in $\mathrm{Abu}$ Madi Formation of the development lease have a limited perspective chance and in order to continue the exploration activity in the Block, other possible targets, such as Abu Madi other levels, Qawasim and Qantara formations should be investigated (Matresu et al., 2016). So, new work has started, to find new opportunities. According to the results of work, new successful wells have been drilled, with huge added reserves in 2015.

\subsection{Location of the Study Area}

Nidoco Field is located at the shoreline of Egypt's Northern Coast, to the east of Lake Burullus. The concession extends onshore and offshore, through the northern part of Egypt (Matresu et al., 2016). The development lease area is $187 \mathrm{~km}^{2}$, divided into two parts $127.7 \mathrm{~km}^{2}$ offshore and $59.3 \mathrm{~km}^{2}$ onshore (Fig. 1).

\subsection{Aim of the Present Study}

The main objectives of this paper are:

- To interpret and create maps for the key seismic horizons, including the main two reservoirs (Level-2 and Level-3).

- To interpret the well logs and to determine the petrophysical characteristics in the area under investigation. These characteristics include; shale content, effective porosity, water and hydrocarbon saturations and reservoir thickness.

- To detect accordingly, new exploration and development potentials.

These objectives were carried out, using a complete integration of the geologic, geophysical and petrophysical data, in order to identify the prospective hydrocarbon locations, by using well $\operatorname{logs}$ and seismic data.

\section{Materials and Methods}

This study has been accomplished through the integrated interpretation of the available geologic, geophysical, petrophysical and sedimentologic data. The data used in the present study include the following:

\subsection{Seismic Data}

Thirty seismic lines, covering the studied area, were used to trace and detect the seismic features of the reservoir levels within the study layers. Fifteen seismic Cross-Lines, eight seismic In-Lines and seven seismic Arbitrary-Lines were used in this study. 
Different seismic surveys were acquired in the area of study, through different times. The onshore area is covered by 3D high quality Land Seismic data over a total area of 180 $\mathrm{Km}^{2}$, while the Offshore area is covered by 3D (OBC) high quality Seismic data, over a total area of $400 \mathrm{Km}^{2}$ (Matresu et al., 2016). The study area is situated almost in the merged part between the 3D marine and land surveys. Due to the fact that, the resolution of the seismic data is not so accurate at the shore line, due to the low data folding, it is recommended to be caution, while interpreting this merged zone (Talaat $\boldsymbol{e t}$ al., 2017).

\subsection{Wells Data}

The formation evaluation, which carried out on the study area, used eight wells (Nidoco-6, Nidoco-7, Nidoco-9, Nidoco-10, Nidoco-11_ST3, NidocoNorthwest-2, Nidoco-Northwest-3 and Nidoco-North-1). However, the available well data are: Composite logs, Mud logs, Gamma-Ray logs, Spectral Gamma-Ray logs (Potassium, Thorium and Uranium), Caliper log, Sonic log, Density log, Neutron log, Photoelectric Factor (PEF), Resistivity logs (flushed, shallow, medium and deep zones) and Bottom Hole Temperature (BHT). In addition, five Vertical Seismic Profiles (VSP) and Check shot surveys had been recorded in five wells selected across the studied area.

\subsection{Softwares}

DecisionSpace Geosciences (DSG), Interactive Petrophysics (IP) and Microsoft Office are the softwares used for analyzing, processing, interpreting and presenting the final results.

\section{Results and Discussion}

The seismic reflection and petrophysical interpretations are the focus of this study. The geophysical interpretation was carried out, in parallel, with the petrophysical evaluation, as described in the following paragraphs. Before going in details, the stratigraphic units of the study area are introduced in (Fig. 2).

\subsection{Seismic to Well Tie}

In order to correctly identify the main acoustic markers, representing the chronologic gas sand levels of Abu Madi and Qawasim Fms reservoirs, and to tie the well to seismic data, the synthetic seismograms of seven studied wells (one of them is only presented in this publication) were generated from the calibrated sonic and density logs.

Seismic volume has a normal polarity in this study. Peak represents increase in the seismic velocities (Positive Acoustic Impedance). Trough represents decrease in the seismic velocities (Negative Acoustic Impedance). The seismic volume is in zero-phase.

\subsubsection{Synthetic Seismogram of N- 10 Well}

The studied section has a complete log coverage of sonic and density. A velocity survey (VSP) was available for this well and the corresponding timedepth table was used, as a starting point, to transfer the well logs to time domain. The time-depth table is shifted down by $36.7 \mathrm{~ms}$, after applying the time-depth table of the constructed synthetic seismogram. (Fig. 3) shows the result of the well-to-seismic tie, which is good in terms of cross-correlation (59\%). 
As shown in (Fig. 3), Level-2 Base is represented by an acoustic impedance decrease, corresponding to a high amplitude trough, while the top of the gas-bearing sand of Level-3A has more defined acoustic impedance decrease, corresponding to a high amplitude trough. Level-3 Base (Level-3 Lower Top) is a significant increase of the acoustic impedance, corresponding to a high amplitude peak, while the top of Serravallian Sidi Salem Fm shales is not presented in the synthetic seismogram, because of the missed sonic data at the mentioned top.

\subsection{Seismic Interpretation and Geologic Cross-Sections}

On the line of clarifying the relationships between the structural and stratigraphic elements implied in Nidoco field, this study undertakes designating thirty depth geologic cross sections (one of them only presented in this publication) derived from the time seismic sections (Abdel Aal et al., 2000). The time seismic lines have been reflected on depth cross sections, after using the well velocity surveys and the generated velocity maps for time to depth conversion. Seismic cross-line and its geologic cross section base map as shown in (Fig. 1). In the following interpreted seismic sections, the peak (Red) represents increase in the seismic velocity and the trough (Black) represents decrease in the seismic velocity, while the zero crossing is (White).

The Interpreted Horizons are:

1. Level-1 by Brown line;

2. Messinian Shale by Green line;

3. Level-2 by Orange line;

4. Level-2A by Violet line;

5. Level-3A by Sky Blue line;

6. Level-3 by Pink line;
7. Level-3 Lower by Lime line;

8. Bottom Abu Madi by Blue Zigzag line;

9. Unit-A by Red line;

10. Unit-A1 by Light Violet line;

11. Unit-B by Dark Orange line;

12. Unit- $\mathrm{C}$ by Aqua line;

13. Unit-D by Turquoise line;

14. Serravallian by Dark Purple line.

\subsubsection{Seismic Cross-Line (11173)}

This cross-line is East- West oriented (Figs. 4a and 4b), that located at the central part of the field. The line shows the rock incision and the following infilling of Abu Madi Fm levels along the axis of the paleo-valley (El Heiny et al., 1990), with high structural activities. The main reservoir (Level-2) appears, as clear as bright spot at the western side of this section. In Level-2 reflector, the signal begins to weaken eastward, due to a progressive shaling out and down dip structure. Other bright spots (Level-3A and Level3 ) are observed in the section and are produced by the presence of slow gasbearing sandstone bounded by shales from above and below. The seismic bright spots are not well defined everywhere, due to the lateral facies and lithologic change. Level-3 Lower appears in this section. The section shows the deep erosion of Abu Madi paleo-valley in the field and the increase in thickness of Abu Madi Fm at the central part of the field. Complete section of Qawasim units is preserved at the eastern and western sides of the section, while Qawasim units are mostly eroded by $\mathrm{Abu}$ Madi incision in the central part of the section (El Heiny and Enani, 1996). The contact unconformity surface, between the highly dipping Qawasim units with strong reflectivity (above the unconformity surface) and the underlying thick shales of the 
Serravallian Sidi Salem Fm with faint reflectivity is very clear and evident.

Six normal faults were observed at the western and central parts of the section (Fault-68, Fault-60, Fault-73, Fault-55, Fault-51 and Fault-57). The two normal faults (Fault-55 and Fault-51) formed step fault blocks. In this section, Fault68 and Fault-73 show an increase in the depositional accommodation space in this part (Abdel Aal et al., 1994). The Fault-57 formed a horst block with Fault-51. Generally, the Late Miocene section has extensional rifting structures, as it is highly dissected by normal faults.

This section crossed three studied wells (N-NW-3, N-9 and N-7), which gave more understanding of the described section. N-NW-3 well, stopped drilling after entering Level-2, as gas-bearing sandstone reservoir, which reflected on the behavior of a strong trough amplitude at well location. N-9 well was drilled at the central part of Abu Madi paleo-valley and entered all the Abu Madi levels. Tops of Level2, Level-2A, Level-3A, Level-3 and Level-3 Lower are very clear on the seismic section and the scouring of Bottom Abu Madi Fm is remarkable. Almost all of Qawasim units were eroded in the well location. Clear section of Serravallian Sidi Salem Fm shales was investigated by this well. N7 well gives more control for the eastern part of the field and the boundary of Abu Madi Paleo-Valley. N-7 well did not enter any of Abu Madi levels. On the other hand, it has a complete section of Qawasim units. All of Qawasim units do not have positive hydrocarbon results in this well, and the high amplitude reflectivity is due to lithologic and facies change (Talaat $\boldsymbol{e t}$ al., 2016). Clear section of Serravallian
Sidi Salem Fm shales was investigated by this well, too. The time-depth table of the three wells shows very good matching with the seismic data.

\subsection{Petrophysical Evaluation (Computer Processed Interpretation) of the Studied Wells}

One of the features of modern log interpretation is the systematic usage of computer softwares. This makes possible to rapid integration of several logging measurements that acquired separately, with all other available boreholes and geologic information. As a result, the detection and evaluation of potential hydrocarbon-bearing zones can nowadays be generally achieved at the well-site, right after the logging operation (quick-look interpretation) (EI Kadi et al., 2002).

In this study, Interactive Petrophysics software (IP) is developed by Senergy, which has more or less inspired all other similar softwares, is used to evaluate the petrophysical characteristics of the studied formations in the form of litho-saturation cross plots. This Interactive Petrophysics computer program was designed for the quantitative formation evaluation of the open and cased-hole logs.

Figs. (5 and 6) represent the examples obtained from the Interactive Petrophysics software for N-NW-2 and N-9 wells, respectively.

From left to right, the following tracks are constructed:

-The first track: GR log for correlation and the caliper- bit size for open hole condition.

-The second track: well measured depth (MD) and the lithologic interpretation. 
-The third track: well true vertical subsea depth (TVDSS) and the zone names.

-The fourth track: resistivity logs (flushed zone, shallow and deep curves) and the formation tops.

- The fifth track: radioactive porosity input (NPHI and RHOB logs), photo electric factor (PEF) and the density correction (DRHO).

- The sixth track: acoustic porosity input (Sonic DELTA T log).

- The seventh track: reservoir flag and pay flag.

- The eighth track: saturation analysis showing the bulk volume of water and gas.

- The ninth track: porosity analysis, showing the effective porosity, and the bulk volumes of water and gas.

- The tenth track: formation analysis, showing the effective porosity, matrix volume, clay volume, and the bulk volume of water and gas.

\subsubsection{Litho-Saturation Cross-Plot Results of N-NW-2 Well}

Table (1) represents the summary results of the litho-saturation cross-plot of N-NW-2 well, which includes the net reservoir and net pay results. Reference $\log$ is in (Fig. 5).

\subsubsection{Litho-Saturation Cross-Plot Results of N-9 Well}

Table (2) represents the summary results of the litho-saturation cross-plot of N-9 well, which includes the net reservoir and net pay results. Reference $\log$ is in (Fig. 6).

\subsection{Time, Velocity, Depth, Seismic Amplitude, Shale Content, Effective porosity, Hydrocarbon Saturation and Reservoir Thickness Iso-Parametric Maps of the Main Reservoirs}

In this study, the geologic and geophysical features of Late Miocene section were evaluated by studying the characteristics of the different horizons. The study of the two-way time horizons mapping, which generated from seismic interpretation, is very important to understand the main structural elements of the area under investigation. Time maps were generated from the interpolation of the interpreted in-lines and cross-lines over the study area.

Seismic velocity values, which deduced from the process of seismic to well tie analysis, are generally varied vertically and laterally. So, the study of seismic velocity was carried out through two main stages. The first stage is the actual recorded time-depth tables at the well locations (VSP), while the second stage is the creation of synthetic seismograms. Average velocity map for each horizon was created, using the available mentioned data.

All the depth structural contour maps were generated through the depth conversion of the time grid, multiplied by the corresponding average velocity grid and divided by two changes (Talaat et al., 2016); this produced the depth maps of the selected horizons. The depth structural contour maps are presented, to give a complete vision about the main structural features and the structural closures, which considered as the main hydrocarbon trapping element in the area of study.

Lateral variation of the seismic wave amplitudes were studied, through a 
number of iso-parametric maps, which reflected the distribution of the sandstone reservoirs and gave an idea about the fluids content of this reservoir (gas or water) change (Talaat et al., 2017). Full-stack amplitude map was generated for every horizon. The study of these parameters on maps are very important, for judging the lithologic and fluid contents lateral variations and the factors controlling them, which may be either structural, stratigraphic or both.

Shale content is a quantitative function of $\log$ analysis. It is considered as an important indicator of the reservoir quality, in which lower shale content usually reveals a better reservoir quality. Shale content map was generated for every horizon.

Effective porosity is the most significant petrophysical character in the evaluation of hydrocarbon potentiality. The linear structural elements may affect porosity development, which have a great influence on porosity (El Kadi et al., 2002). Effective porosity was generated for every horizon.

Determination of hydrocarbon saturation is the main target in the current study. Hydrocarbon saturation map for each horizon was created to validate the potentiality of the area.

The reservoir thickness maps were constructed, to illustrate the lateral variation of thinning and thickening of the effective thickness of the studied zones.

\subsubsection{Level-2 Maps}

Figs. (7a and 7c) represent the time and depth structural contour maps of Level-2. As shown in the figure, the main structural trend of Level-2 is the
Northwest-Southeast, dipping generally towards the Northern direction. Level-2 was penetrated by seven studied wells (N-6, N-9, N-10, N-11_ST3, N-N-1, NNW-2 and N-NW-3), which used to convert the time to depth.

The southern part shows less values of two-way time relative to the northern part, which reflected later on the shallower depth values toward the South, relative to the North. The central part, especially the western side to the shoreline, is characterized by high structural activity. Several normal faults trending Northwest and West Northwest are observed in this part, and shaped the main structural features of this level (Abdel Aal et al., 1992). Three structural high closures were observed at the top of Level-2. Two of them, toward the West, were tested as gasbearing traps and the one to the East should be tested by a new well in the future. The most southern part of the area shows high structure, but not complete, due to the data limitation at the concession boundary.

Fig. (7b) represents the average velocity map of Level-2, which is used to convert the two-way times to depths. The average velocity values increase relatively to the southern part of the area under investigation, south of the shoreline. The offshore part shows less values of average velocity, due to the presence of water column, that cause less sediment compaction. Also, the part around N-N-1 well shows higher average velocity values, because it is highly compacted, due to the presence of two normal faults, which forming a horst block. The maximum recorded value of the average velocity is 2295 meter/second at $\mathrm{N}-\mathrm{N}-1$ well and the minimum recorded value of the average 
velocity is 2258 meter/second at $\mathrm{N}-10$ well.

Fig. (7d) represents the full stack amplitude map of Level-2. The high amplitude parts, which trending northwest are reflecting the presence of sandstone reservoir in Level-2, while the lower amplitude is reflecting silty sandstone or shale facies. This is proved by the studied wells. Three wells $(\mathrm{N}-\mathrm{N}-$ 1, N-NW-2 and N-NW-3) penetrated clean sandstone in the high amplitude parts, while four wells (N-6, N-9, N-10 and N-11_ST3) penetrated silty facies in the low amplitude parts.

Fig. (7e) represents the shale content of Level-2. As shown in the figure, the shale content increases mainly toward the eastern side and the far Southwest of the area under investigation. The clean sandstone is almost at the central part of the area under investigation, around $\mathrm{N}$ NW-2 and N-NW-3 wells. The maximum recorded value of shale content is $75 \%$ at the East in N-9 well and decreasing gradually to the West, owing minimum value of $14 \%$ at $\mathrm{N}$ NW-2 well.

Fig. (7f) represents the effective porosity distribution map of Level-2. As shown in the figure, it reflects that the effective porosity increases toward the western part of the studied area, within the central part of the paleo-channel, around N-NW-3 and N-NW-2 wells. The effective porosity recorded the maximum value of $19 \%$ at $\mathrm{N}-\mathrm{NW}-3$ well and the minimum value of $2 \%$ is recorded at $\mathrm{N}-10$ well, at the eastern border of the paleo-channel (central part of the studied area).

Fig. (7g) shows the hydrocarbon saturation map for Level-2. This figure reveals that, the hydrocarbon saturation generally increases toward the northwestern side of the studied area. The hydrocarbon saturation recorded the maximum value of $83 \%$ at N-NW-2 well and the minimum value of $0 \%$ is recorded in wells to the East and South.

Fig. (7h) illustrates the reservoir thickness map of Level-2. As shown in the figure, the reservoir thickness increases mainly toward the western side and the far South of the area under investigation, around N-NW-2 and NNW-3 wells. The maximum recorded value of the reservoir thickness is $64 \mathrm{~m}$ at N-NW-3 well and decreasing gradually toward the East at minimum value of $1 \mathrm{~m}$ at $\mathrm{N}-10$ well.

\subsubsection{Level-3 Maps}

Figs. (8a and 8c) represent the time and depth structural contour maps of Level-3. As shown in the figure, the main structural trend of Level-3 is the Northwest-Southeast, dipping generally towards the Northern direction. Level-3 was penetrated by four studied wells (N-6, N-9, N-10 and N-11_ST3), which used to convert the time to depth.

The southern part shows less values of the two-way time, relative to the northern part, which reflected later on shallower depth values toward the South relative to North (Talaat et al., 2016). Few normal faults were observed at the central part of the study area. Four structural high closures were observed at the top of Level-3. The first one is at the central part of the area under investigation. This closure was tested, as gas-bearing trap, by two studied wells (N-9 and N-11_ST3). The second one is at the western border of Level-3, close to the central part of the area under concern. This closure was tested, as gas-bearing trap by one of the 
studied wells (N-6). The third one is at the western border of Level-3, close to the west of $\mathrm{N}-10$ well and to the northwest of N-6 well. This closure is to be tested by a new well in the future. The fourth one is lied towards the most southern part of the area and it is showing high structure, but not complete, due to the data limitation at the concession boundary.

Fig. (8b) represents the average velocity map of Level-3, which is used to convert the two-way time to depth. The average velocity values increase relatively to the southern part of the area under investigation, south of the shoreline. The offshore part shows less values of average velocity, due to the presence of water column, which causes less sediment compaction. The maximum recorded value of the average velocity is 2318 meter/second at N-6 well and the minimum recorded value of the average velocity is 2296 meter/second at N-9 well.

Fig. (8d) represents the full stack amplitude map of Level-3. The high amplitude parts, which trending Northwest, are reflecting the presence of sandstone reservoir in Level-3, while the lower amplitude is reflecting silty sandstone or shale facies. This is proved by the studied wells. Four wells (N-6, N-9, N-10 and N-11_ST3) penetrated clean sandstone in the high amplitude parts. The best quality of sandstone was at N-9 and N-11_ST3 wells, which have the highest amplitude, while the worst quality and less sandstone thickness was at N-6 well, which has less amplitude.

Fig. (8e) represents the shale content of Level-3. As shown in the figure, the shale content increases mainly toward the western side of the area under investigation. The clean sandstone is almost everywhere in the channel. The maximum recorded value of shale content is $20 \%$ to the West at N-10 well and decreasing gradually toward the East as a minimum of 5\% at N-9 and N11_ST3 wells.

Fig. (8f) represents the effective porosity distribution map of Level-3. As shown in the figure, it reflects that, the effective porosity decreases toward the western part of the studied area, and the high effective porosity values are almost everywhere in the channel. The effective porosity recorded the maximum value of $20 \%$ at $\mathrm{N}-9$ and $\mathrm{N}-$ 11_ST3 wells and the minimum value of $14 \%$ is recorded at N-6 well toward the western border of the paleo-channel.

Fig. (8g) shows the hydrocarbon saturation map for Level-3. This figure reveals that, the hydrocarbon saturation generally increases toward the central and southern parts of the studied area. The hydrocarbon saturation recorded the maximum value of $72 \%$ at $\mathrm{N}-9$ well and the minimum value of $0 \%$ is recorded at N-10 well, to the North.

Fig. (8h) illustrates the reservoir thickness map of Level-3. As shown in the figure, the reservoir thickness increases mainly toward the central part of Level-3 channel in the concerned area. The maximum recorded value of reservoir thickness is $59 \mathrm{~m}$ at N-11_ST3 well and decreasing gradually to a minimum of $5 \mathrm{~m}$ at N-6 well toward the border of the channel.

\section{Conclusion}

Nidoco Field is a large gas field located at the central part of the Nile Delta, along the coast of the Mediterranean Sea. The field was discovered in 1993 and put on 
production in 1995, stopped production in 2012, put back on production in 2015 and still producing till the present day.

The seismic interpretations were commenced by generating synthetic seismograms, in order to correctly identify the main acoustic markers, representing the gas sand levels of Abu Madi and Qawasim reservoirs and to tie the wells to the seismic data. So, the seismic volume was found to have normal polarity in this study. Peaks represent increase in the seismic velocity and density (Positive Acoustic Impedance). Troughs represent decrease in the seismic velocity and density (Negative Acoustic Impedance). The seismic volume was found in zerophase.

After good seismic to well tie, detailed seismic interpretation and accordingly geologic cross sections were generated. In addition, a series of time, velocity, depth and seismic amplitude maps were constructed for the main studied reservoirs, to have the geologic features. The study of the twoway time horizon mapping, which generated from the seismic interpretation, is to understand the main structural features of the area under investigation. Seismic velocity values, which deduced from the process of seismic to well tie analysis, are generally varied vertically and laterally. Average velocity map for each horizon was created and showed higher velocity values to the South of the shoreline than the north of the shoreline. The offshore part showed less values of average velocity, due to the presence of water column, which causes less sediment compaction.
The depth structure contour maps are presented to give complete vision about the main structural features and the structural closures, which are considered the main hydrocarbon trapping elements in the area of study. The southern part showed shallower depth values, relative to the northern (general dip towards the Northwest). In addition, the central part, especially, the western side of the shoreline is characterized by high structural activity. Several normal faults trending Northwest and West-Northwest are observed and shaped the main structural impelications of the studied area (Abdel Aal et al., 1992). Several structural closures were observed at the tops of the studied reservoirs. Some of these closures were tested by $(\mathrm{N}-\mathrm{NW}-2, \mathrm{~N}-$ NW-3 and N-N-1) wells, as huge gasbearing traps and others are recommended to be tested by new promising wells in the future.

Lateral variation of the seismic wave amplitudes were studied, through a number of iso-parametric maps, which reflected the distribution of the sandstone reservoirs and gave an idea about the fluids content of this reservoir (gas or water). Full stack amplitude maps were generated for the main horizons. Several levels and units showed strong amplitudes, which indicated the presence of hydrocarbon.

All the petrophysical characteristics of the studied wells were represented vertically in the form of litho-saturation cross-plots, as inferred from computer processed interpretation (CPI). The lateral variations of the mentioned petrophysical characteristics were represented in the form of isoparametric maps ((shale content $\left(\mathrm{V}_{\mathrm{sh}}\right)$, effective porosity $\left(\varnothing_{\text {eff }}\right)$, hydrocarbon 
saturation $\left(\mathrm{S}_{\mathrm{hr}}\right)$ and reservoir thickness $\left.\left(\mathrm{H}_{\mathrm{eff}}\right)\right)$.

The integration of all the mentioned data have been allowed the detection of the best locations to be drilled and huge gas discoveries (through N-NW-2, NNW-3 and N-N-1 wells) have been achieved and the production started again from Nidoco Field. Beside that, other new locations are recommended to be drilled, as exploratory and development wells, to produce more hydrocarbons from the study area, especially from Level-2 toward the northwestern part of the study area and Level-3 toward the northwestern, southern and eastern parts of the study area, which still showing high hydrocarbon potentialities.

\section{Acknowledgments}

The authors would first like to thank Belayim Petroleum Company for providing the data. In addition, they would like to thank the Geology Department of the Faculty of Science, Al-Azhar University, for their cooperation. Finally, the authors are very grateful to the Editors of the publishing Journal, for their great efforts and valuable comments.

\section{References}

Abdel Aal A., R.A. Dav and J. J. Lelek, 1992. "Structural Evolution and Styles of The Northern Sinai, Egypt. EGPC $11^{\text {th }}$ Petroleum Exploration and Production Conference, V1, 546-562.

Abdel Aal A., Price R.J., Vaital J.D. and Shrallow, J.A., 1994. Tectonic Evolution of the Nile Delta, Its Impact on Sedimentation and Hydrocarbon Potential. EGPC 12 ${ }^{\text {th }}$ Petroleum Exploration and Production Conference, V1, 19-34.

Abdel Aal A., El Barkooky A., Gerrits M., Meyer H., Schwander M. and Zaki H., 2000. Tectonic Evolution of the
Eastern Mediterranean Basin and its Significance for the Hydrocarbon Prospectivity of the Nile Delta UltraDeepwater Area. proceedings of MOC, 717-754.

El-Kadi H. H., E. A. Abd EI-Gawad and A. M. Ghazaly, 2002. Reservoir Characterization of the Upper Cretaceous Formations at Dabaa- Al Amein Area, North Western Desert, Egypt. J. Appl. Geophs., Vol. 1, September 2002, 33-52.

Dolson JC, Boucher PJ, Siok J and Heppard PD, 2005. Key Challenges to Realizing Full Potential in an Emerging Giant Gas Province: Nile Delta/ Mediterranean Offshore, Deep Water, Egypt. Petrol Geol Conf series 6:607624.

El Heiny I., R Rizk and M. Hassan, 1990. Sedimentological Model for Abu Madi Reservoir Sands, Abu Madi Field, Nile Delta, Egypt. EGPC $10^{\text {th }}$ Petroleum Exploration and Production Conference, V2, pp. 515-551.

El Heiny I. and Enani N, 1996. Regional stratigraphic interpretation of Neogene sediments, northern Nile Delta. EGPC $11^{\text {th }}$ Petroleum Exploration and Production Conference, pp. 270-290.

Matresu J., Bettazzoli P., Bertello F., Nassar M., Bricchi G., Talaat A. and Zaki A., 2016. The Nooros Discovery Offshore Central Nile Delta Basin, Egypt; Geological Framework and Hydrocarbons Implications. Alexandria, Egypt, Proceedings of MOC 2016.

Talaat A., El Belasy A.M., Fawzy A., Mustafa Omar and Matresu J., 2016. The Role of AVO in Prospect Risk Assessment for Successful Exploration in Abu Madi West Block, Egypt. Alexandria, Egypt, proceedings of MOC 2016.

Talaat A., El Belasy A.M., Mustafa Omar and Matresu J., 2017. Application of Seismic Inversion for Successful Hydrocarbon Exploration in the Nile Delta, Egypt: Noroos Field a Case Study. Ravenna, Italy, proceedings of OMC 2017. 
Table 1: Summary Results of Litho-Saturation Cross-Plot of N-NW-2 Well (Reservoir Summary).

\begin{tabular}{|c|c|c|c|c|c|c|c|c|}
\hline \multirow{2}{*}{$\begin{array}{c}\text { Zone } \\
\text { Name }\end{array}$} & Top & Bottom & Gross & Net & N/G & $\overline{\text { AvPhi }}$ & $\overline{\mathrm{Av} S w}$ & $\overline{\text { AvVcl }}$ \\
\hline & mTVDSS & mTVDSS & mTVDSS & mTVDSS & dec & dec & dec & dec \\
\hline \multirow{2}{*}{ Level-2 } & 4249 & 4340 & 90.2 & 82.9 & 0.92 & \multirow{2}{*}{0.17} & \multirow{2}{*}{0.17} & \multirow{2}{*}{0.14} \\
\hline & -3233 & -3293 & 59.3 & 54.5 & 0.92 & & & \\
\hline \multirow{2}{*}{ Unit-B } & 4454 & 4514 & 59.9 & 2.1 & 0.04 & \multirow{2}{*}{0.13} & \multirow{2}{*}{0.93} & \multirow{2}{*}{0.24} \\
\hline & -3368 & -3408 & 39.4 & 1.4 & 0.04 & & & \\
\hline \multirow{2}{*}{ Unit-D } & 4668 & 4802 & 133.7 & 72.5 & 0.54 & \multirow{2}{*}{0.14} & \multirow{2}{*}{1.00} & \multirow{2}{*}{0.31} \\
\hline & -3509 & -3597 & 88.4 & 48.0 & 0.54 & & & \\
\hline
\end{tabular}

Table 2: Summary Results of Litho-Saturation Cross-Plot of N-NW-2 Well (Pay Summary).

\begin{tabular}{|c|c|c|c|c|c|c|c|c|}
\hline $\begin{array}{c}\text { Zone } \\
\text { Name }\end{array}$ & Top & Bottom & Gross & Net & N/G & AvPhi & Av Sw & AvVcl \\
\cline { 2 - 9 } & mTVDSS & mTVDSS & mTVDSS & mTVDSS & dec & dec & dec & dec \\
\hline \multirow{2}{*}{ Level-2 } & 4249 & 4340 & 90.2 & 82.9 & 0.92 & \multirow{2}{*}{0.17} & \multirow{2}{*}{0.17} & \multirow{2}{*}{0.14} \\
\cline { 2 - 10 } & -3233 & -3293 & 59.3 & 54.5 & 0.92 & & & \\
\hline
\end{tabular}

Table 3: Summary Results of Litho-Saturation Cross-Plot of N-9 Well (Reservoir Summary).

\begin{tabular}{|c|c|c|c|c|c|c|c|c|}
\hline \multirow{2}{*}{$\begin{array}{l}\text { Zone } \\
\text { Name }\end{array}$} & Top & Bottom & Gross & Net & $\mathbf{N} / \mathbf{G}$ & AvPhi & $\mathrm{Av} \mathbf{S w}$ & AvVcl \\
\hline & mTVDSS & mTVDSS & mTVDSS & mTVDSS & dec & dec & dec & dec \\
\hline \multirow{2}{*}{ Level-1 } & 3237 & 3248 & 10.8 & 1.2 & 0.11 & \multirow{2}{*}{0.12} & \multirow{2}{*}{0.95} & \multirow{2}{*}{0.04} \\
\hline & -3202 & -3213 & 10.8 & 1.2 & 0.11 & & & \\
\hline \multirow{2}{*}{ Level-2 } & 3264 & 3294 & 30.0 & 2.0 & 0.07 & \multirow{2}{*}{0.09} & \multirow{2}{*}{1.00} & \multirow{2}{*}{0.15} \\
\hline & -3229 & -3259 & 30.0 & 2.0 & 0.07 & & & \\
\hline \multirow{2}{*}{$\begin{array}{c}\text { Level- } \\
3 \mathrm{~A}\end{array}$} & 3344 & 3363 & 19.2 & 4.3 & 0.22 & \multirow{2}{*}{0.15} & \multirow{2}{*}{0.95} & \multirow{2}{*}{0.34} \\
\hline & -3308 & -3328 & 19.2 & 4.3 & 0.22 & & & \\
\hline \multirow{2}{*}{$\begin{array}{c}\text { Level-3 } \\
\text { Main }\end{array}$} & 3394 & 3428 & 34.3 & 30.8 & 0.90 & \multirow{2}{*}{0.18} & \multirow{2}{*}{0.43} & \multirow{2}{*}{0.05} \\
\hline & -3358 & -3392 & 34.3 & 30.8 & 0.90 & & & \\
\hline \multirow{2}{*}{$\begin{array}{c}\text { Level-3 } \\
\text { Lower }\end{array}$} & 3476 & 3541 & 65.3 & 62.7 & 0.96 & \multirow{2}{*}{0.19} & \multirow{2}{*}{0.98} & \multirow{2}{*}{0.13} \\
\hline & -3440 & -3506 & 65.3 & 62.7 & 0.96 & & & \\
\hline
\end{tabular}

Table 4: Summary Results of Litho-Saturation Cross-Plot of N-9 Well (Pay Summary).

\begin{tabular}{|c|c|c|c|c|c|c|c|c|}
\hline \multirow{2}{*}{$\begin{array}{c}\text { Zone } \\
\text { Name }\end{array}$} & Top & Bottom & Gross & Net & $\mathbf{N} / \mathbf{G}$ & $\overline{\text { AvPhi }}$ & Av Sw & AvVcl \\
\hline & mTVDSS & mTVDSS & mTVDSS & mTVDSS & dec & dec & dec & dec \\
\hline \multirow{2}{*}{$\begin{array}{c}\text { Level- } \\
3 \mathrm{~A}\end{array}$} & 3344 & 3363 & 19.2 & 0.2 & 0.01 & \multirow{2}{*}{0.20} & \multirow{2}{*}{0.71} & \multirow{2}{*}{0.05} \\
\hline & -3308 & -3328 & 19.2 & 0.2 & 0.01 & & & \\
\hline \multirow{2}{*}{$\begin{array}{c}\text { Level-3 } \\
\text { Main }\end{array}$} & 3394 & 3428 & 34.3 & 27.4 & 0.80 & \multirow{2}{*}{0.19} & \multirow{2}{*}{0.39} & \multirow{2}{*}{0.02} \\
\hline & -3358 & -3392 & 34.3 & 27.4 & 0.80 & & & \\
\hline
\end{tabular}




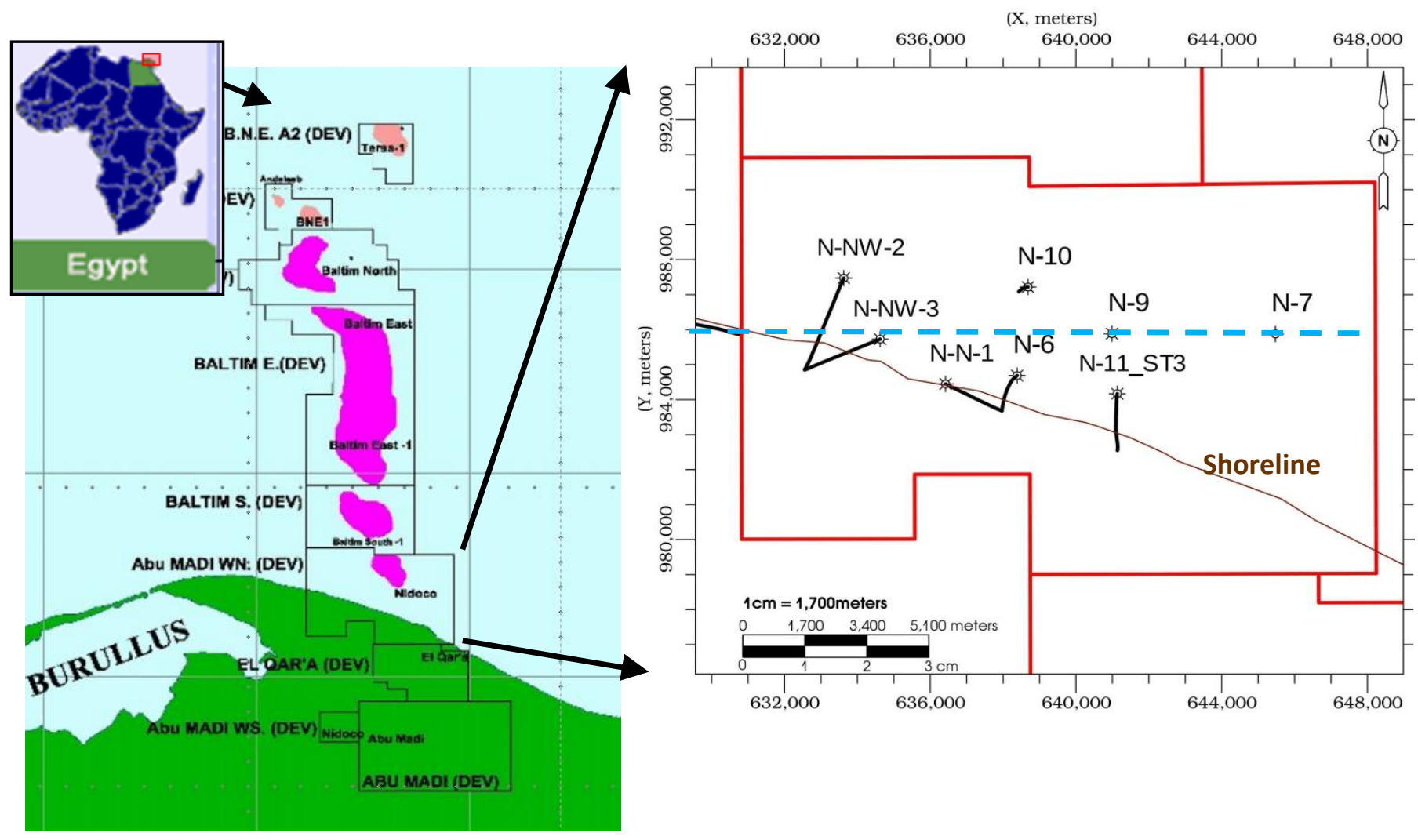

Fig. 1: Location Map of the Study Area, Showing Wells, Seismic Line and the Geologic Cross Section location.

Fig. 2: Stratigraphic Units of the Study Area.

\begin{tabular}{|c|c|c|c|c|}
\hline Epoch & Age & Formation & Sub-Levels & Lithology \\
\hline \multirow[b]{2}{*}{ Pliocene } & \multirow[b]{2}{*}{ Zanclean } & \multirow{2}{*}{$\begin{array}{l}\text { Kafr El } \\
\text { Sheikh }\end{array}$} & --- & Shale \\
\hline & & & Level-1 & $\begin{array}{l}\text { Siltstone and } \\
\text { Sandstone }\end{array}$ \\
\hline \multirow{20}{*}{$\begin{array}{l}\text { Late } \\
\text { Miocene }\end{array}$} & \multirow{20}{*}{ Messinian } & \multirow{12}{*}{ Abu Madi } & Messinian Sh & Shale \\
\hline & & & Level-2 & $\begin{array}{l}\text { Sandstone and } \\
\text { Siltstone }\end{array}$ \\
\hline & & & Level-2 Base & Shale \\
\hline & & & Level-2A & Siltstone \\
\hline & & & Level-2A Base & Shale \\
\hline & & & Level-3A & $\begin{array}{l}\text { Sandstone and } \\
\text { Siltstone }\end{array}$ \\
\hline & & & Level-3A Base & Shale \\
\hline & & & Level-3 & Sandstone \\
\hline & & & Level-3 Base & Shale \\
\hline & & & Level-3 Lower & Sandstone \\
\hline & & & $\begin{array}{l}\text { Level-3 Lower } \\
\text { Base }\end{array}$ & Shale \\
\hline & & & Bottom Abu Madi & Unconformity \\
\hline & & \multirow{8}{*}{ Qawasim } & Unit-A & $\begin{array}{l}\text { Sandstone and } \\
\text { Siltstone }\end{array}$ \\
\hline & & & Bottom Unit-A & Shale \\
\hline & & & Unit-A1 & $\begin{array}{l}\text { Sandstone and } \\
\text { Siltstone }\end{array}$ \\
\hline & & & Unit-B & $\begin{array}{c}\text { Sandstone and } \\
\text { Siltstone } \\
\end{array}$ \\
\hline & & & Bottom Unit-B & Shale \\
\hline & & & Unit-C & Siltstone \\
\hline & & & Bottom Unit-C & Shale \\
\hline & & & Unit-D & $\begin{array}{l}\text { Sandstone and } \\
\text { Limestone }\end{array}$ \\
\hline $\begin{array}{l}\text { Middle } \\
\text { Miocene }\end{array}$ & Serravallian & Sidi Salem & Serravallian & Shale \\
\hline
\end{tabular}




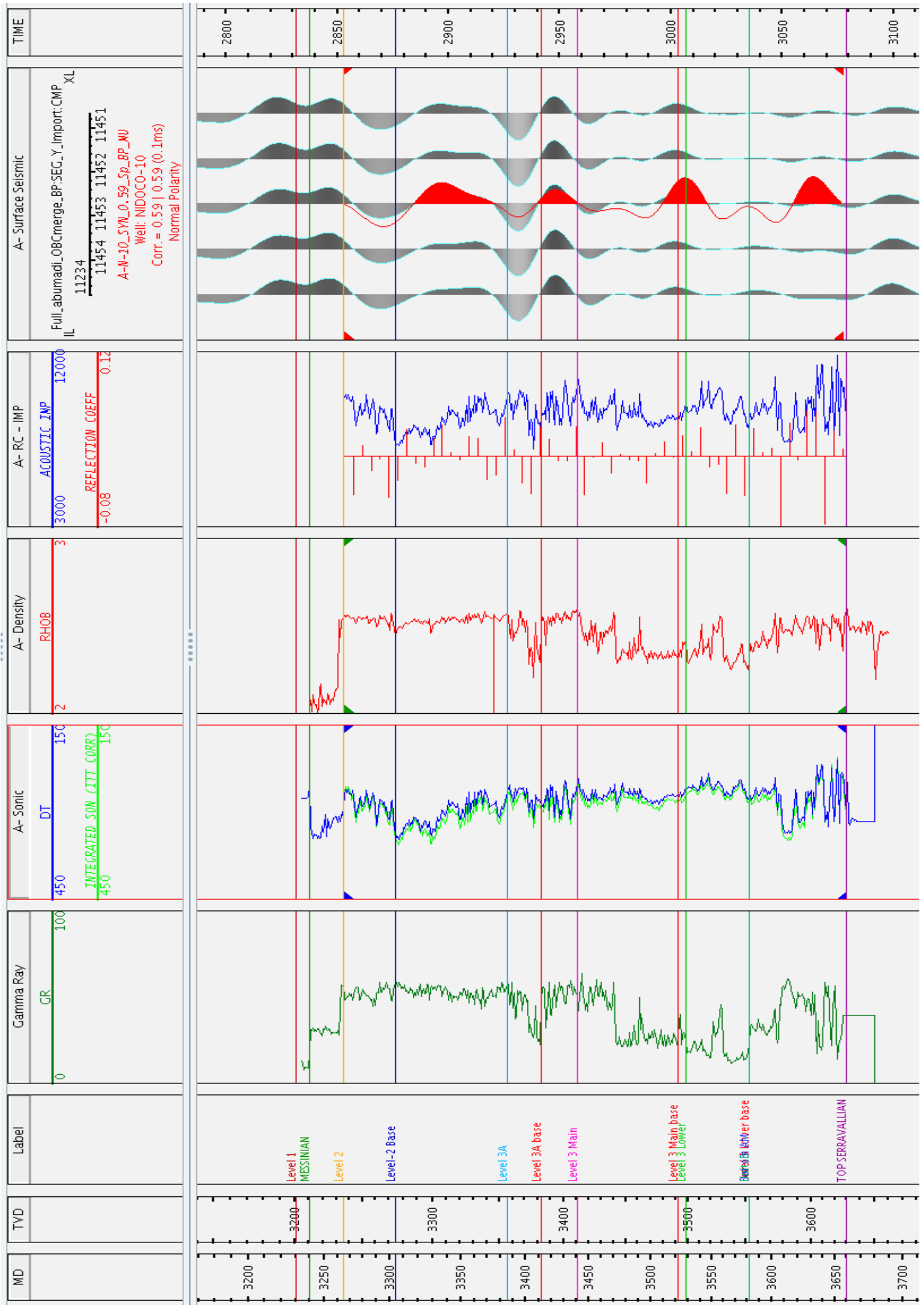

Fig.3: N-10 Well Time-Depth Table of the Velocity Survey and Synthetic Seismogram, after the Cross Correlation Shift. 

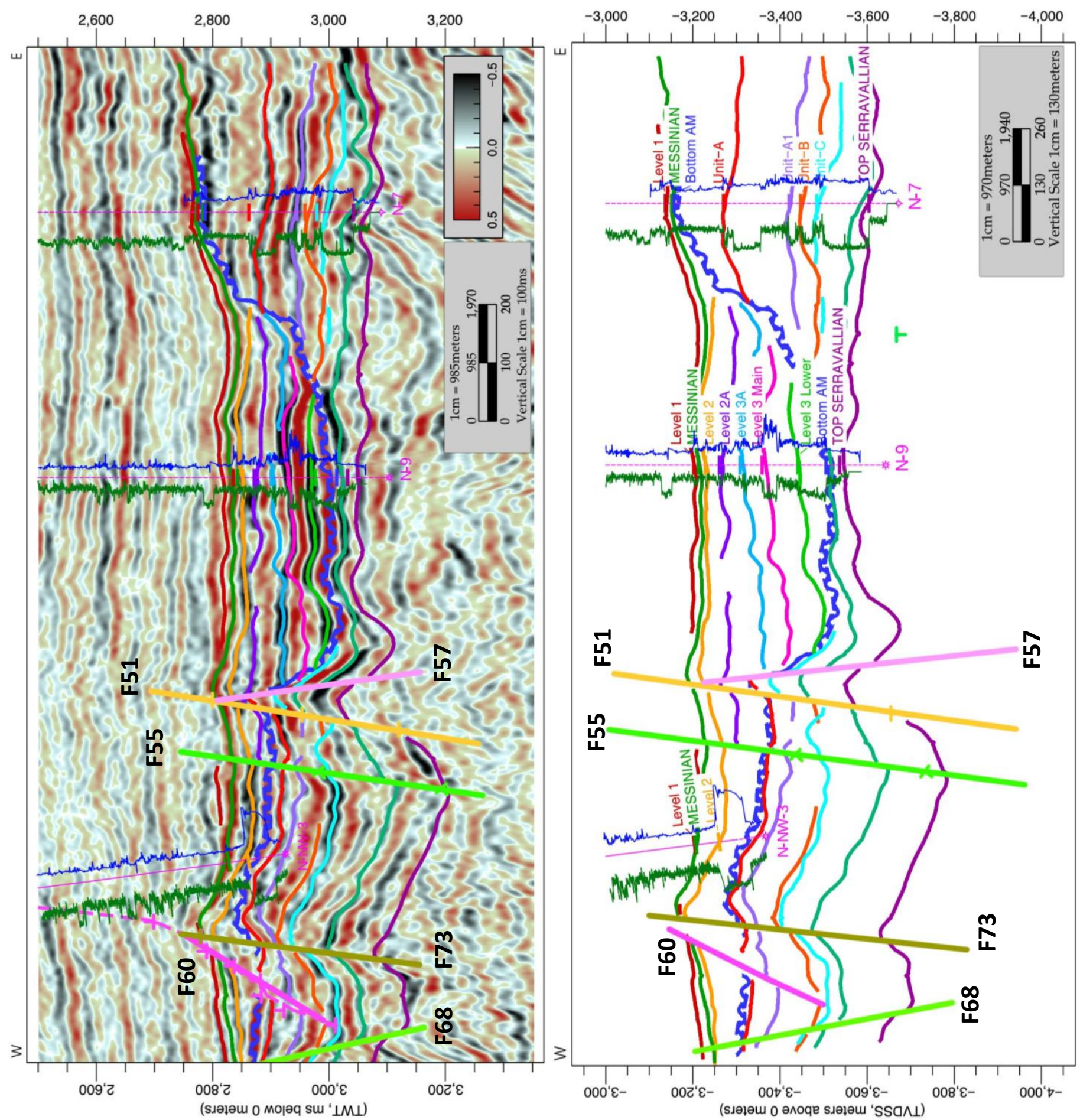

(a)

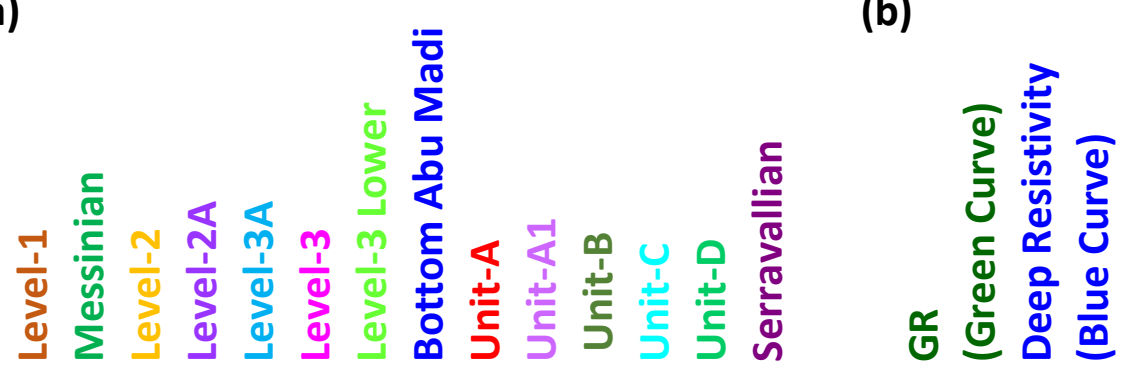

Fig. 4: (a) Interpreted E-W Time Seismic Cross-Line no.11173 (Full Stack);

(b) E-W Depth Geologic Cross-Section (Cross-Line no. 11173). 


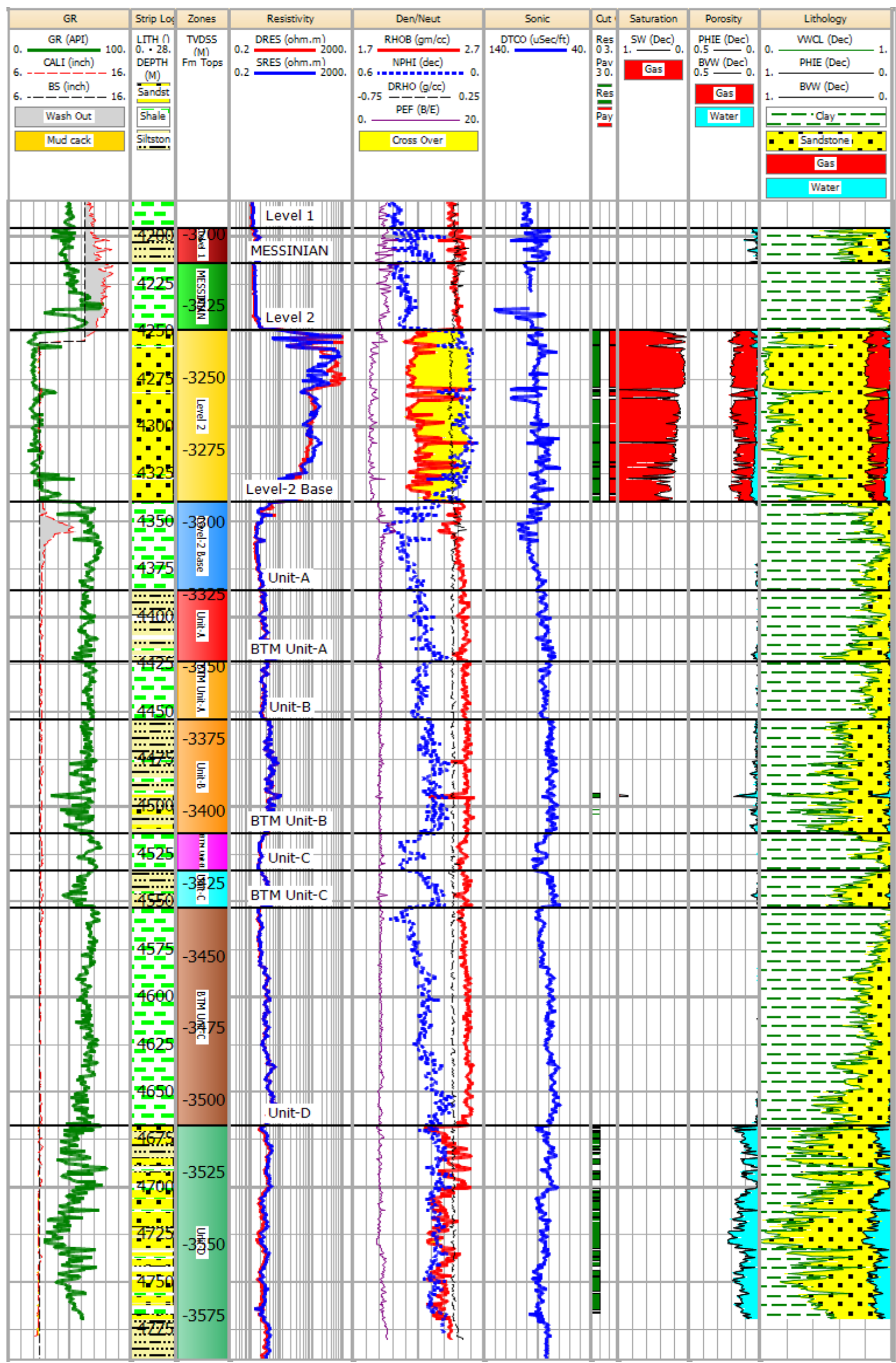

Fig. 5: CPI cross plot, after IP Software application of N-NW-2 Well 
El-Kadi et al., 2022

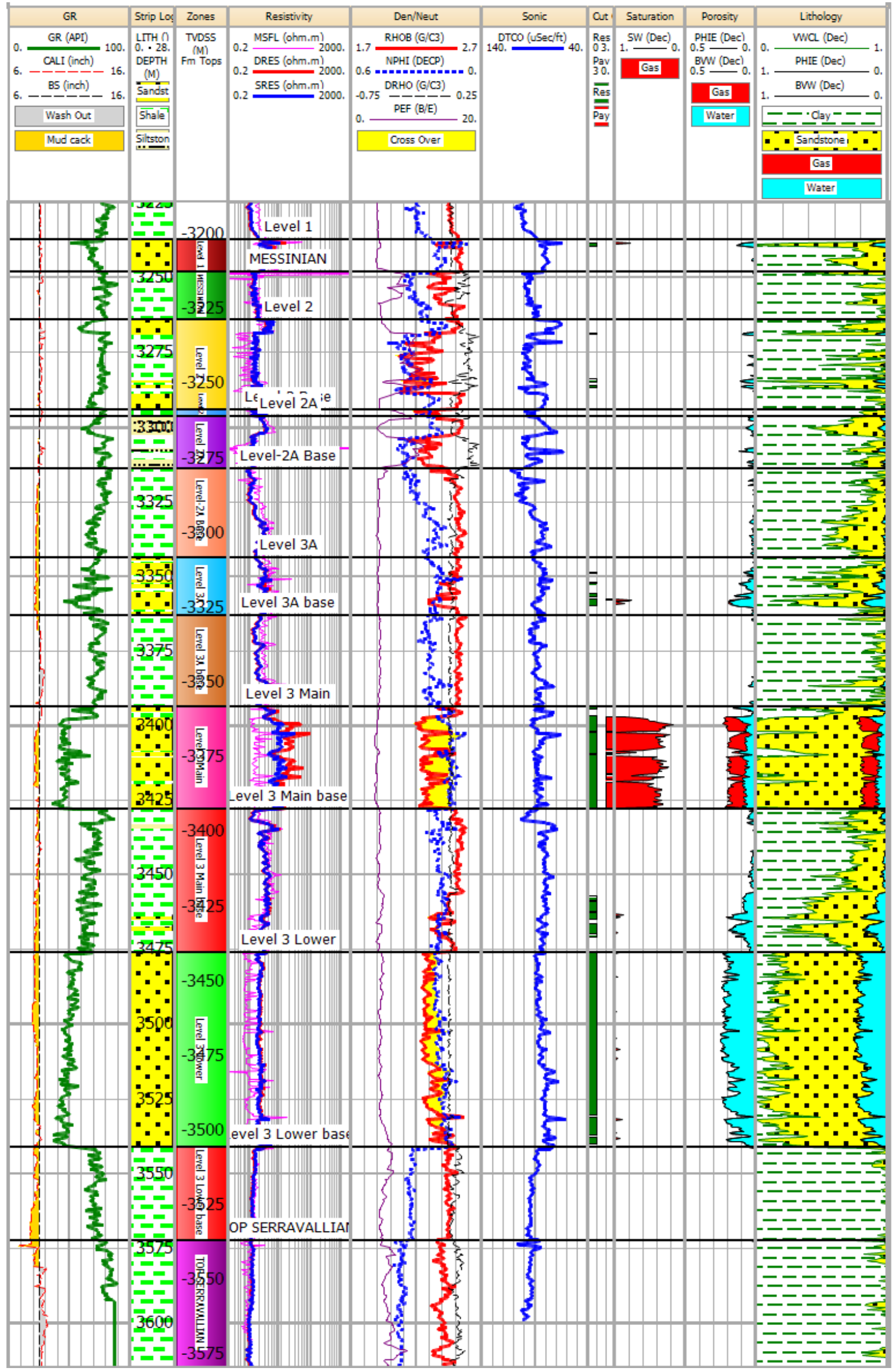

Fig. 6: CPI cross plot, after IP Software Application of N-9 Well. 


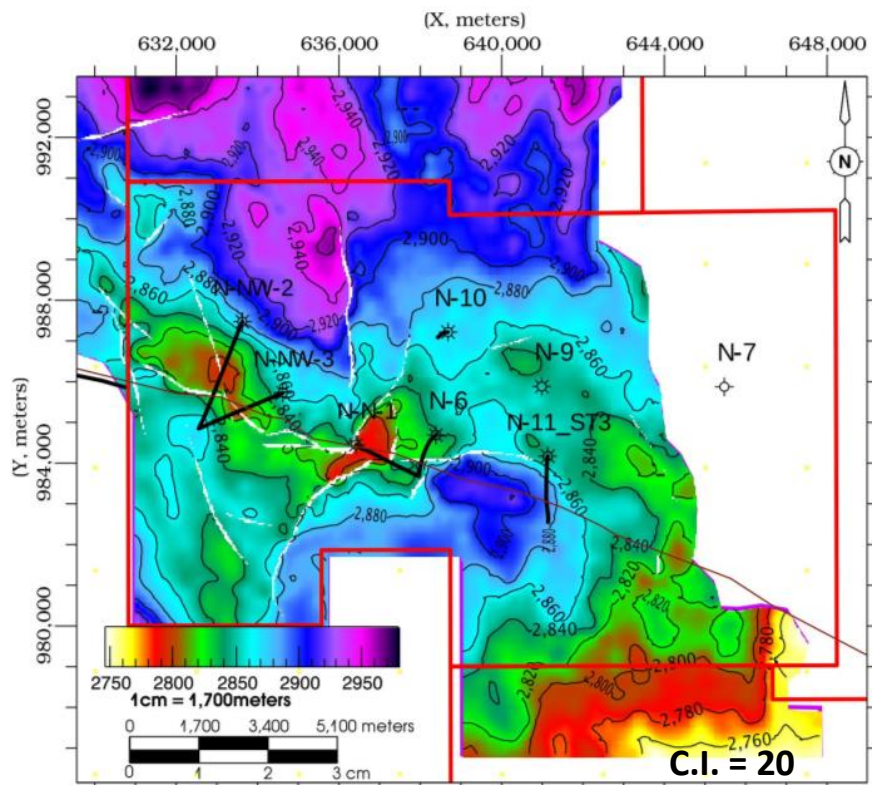

Fig. 7a: Level-2 Time Structural Contour Map.

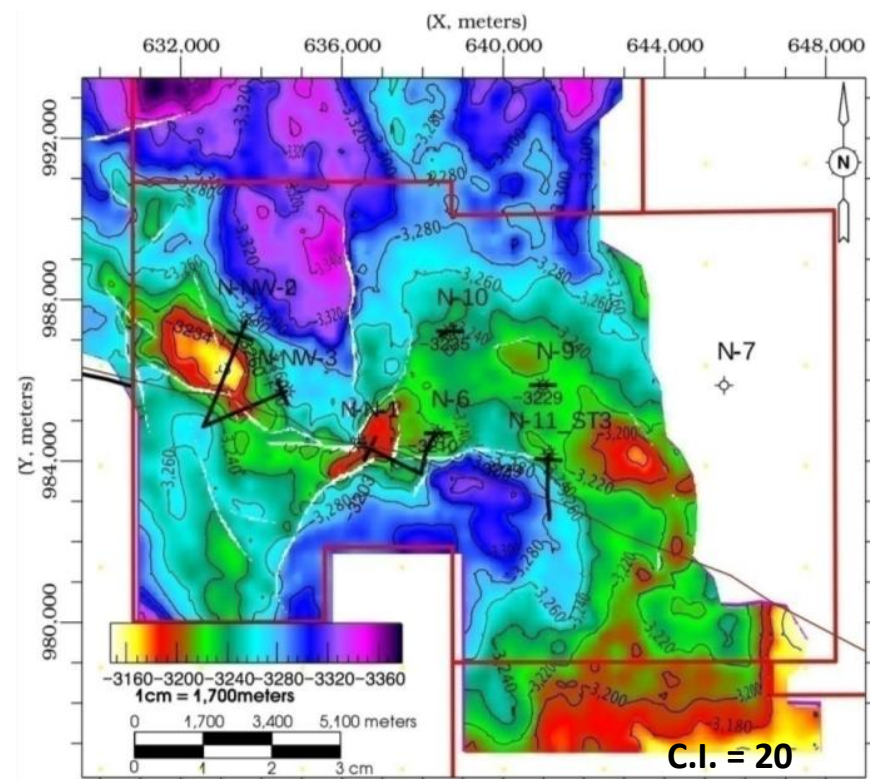

Fig. 7c: Level-2 Depth Structural Contour Map.

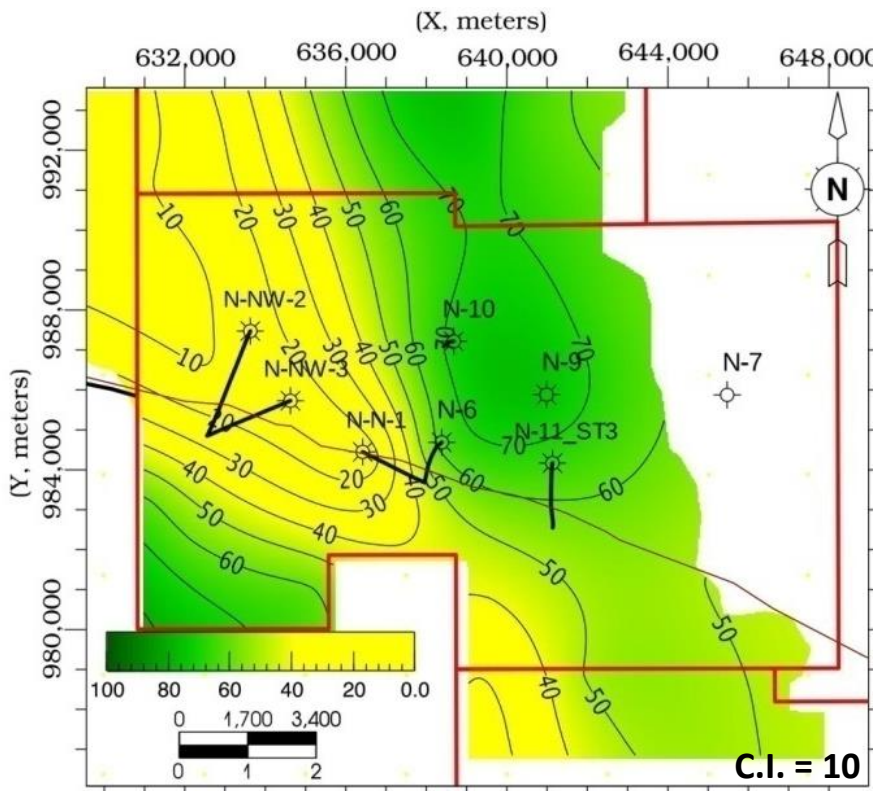

Fig. 7e: Level-2 Shale Content Map (\%).

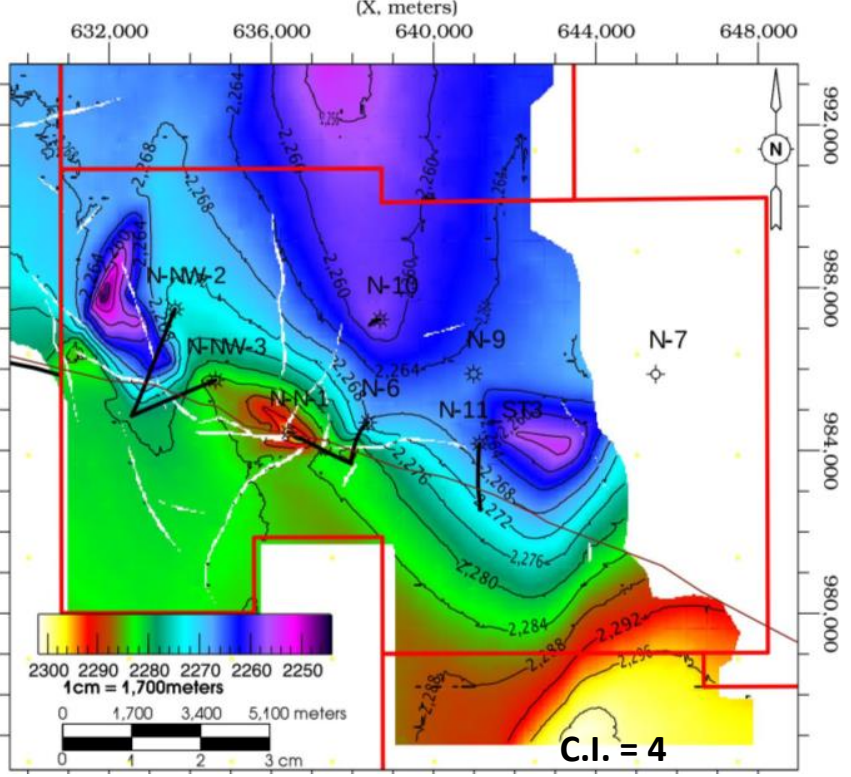

Fig. 7b: Level-2 Velocity Gradient Map.

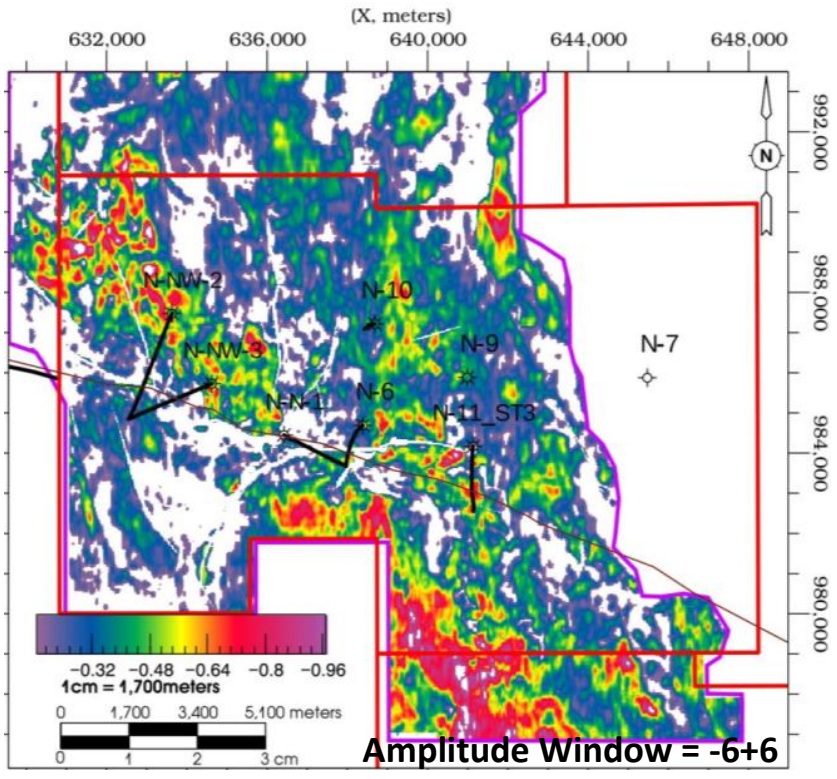

Fig. 7d: Level-2 Full Stack Amplitude Map.

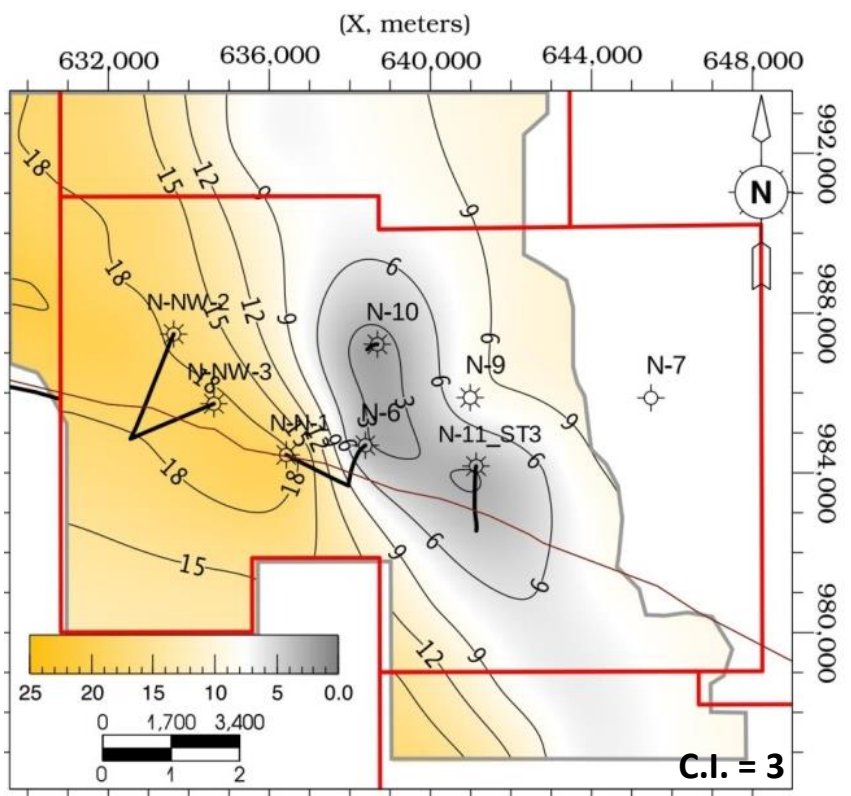

Fig. 7f: Level-2 Effective Porosity Map (\%). 

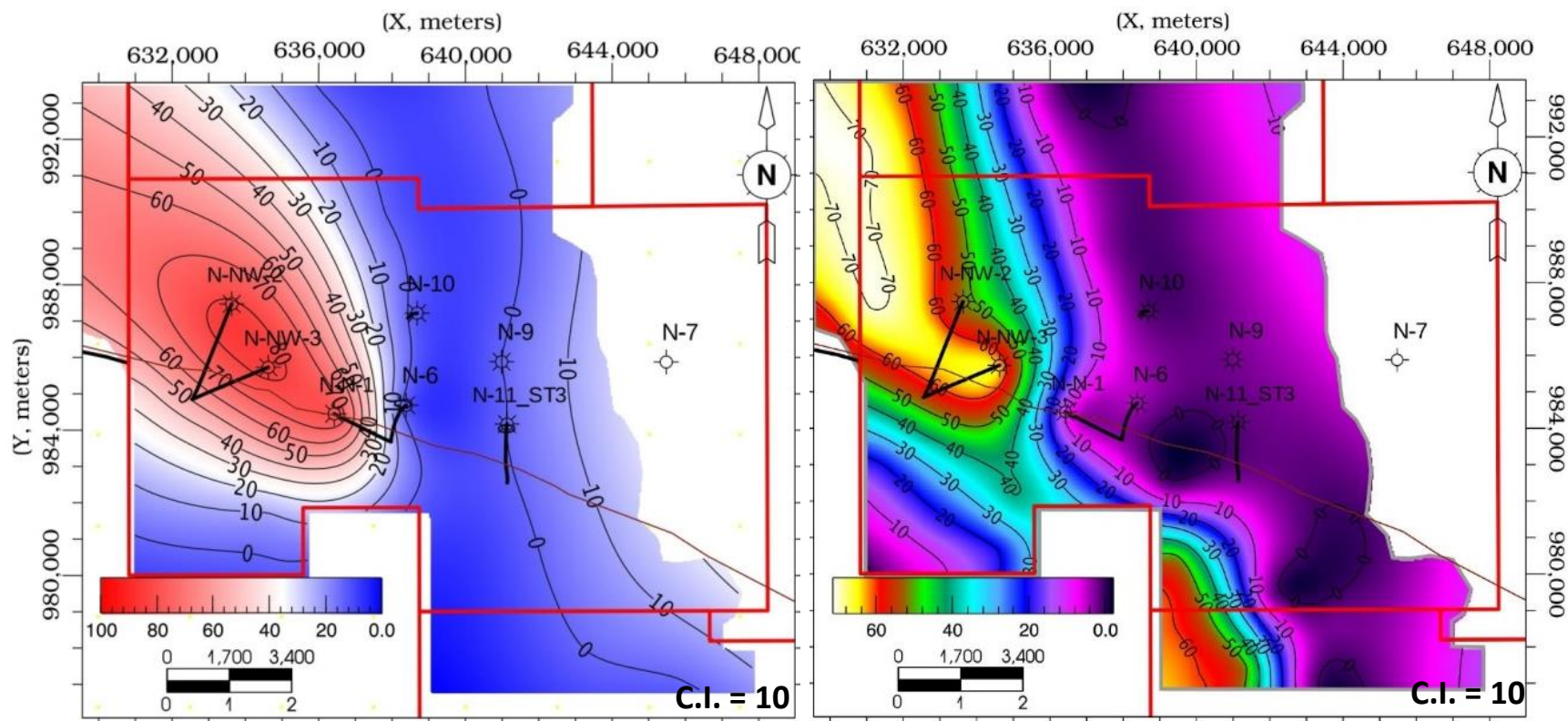

Fig. 7g: Level-2 Hydrocarbon Saturation Map (\%).

Fig. 7h: Level-2 Reservoir Thickness Map (m).

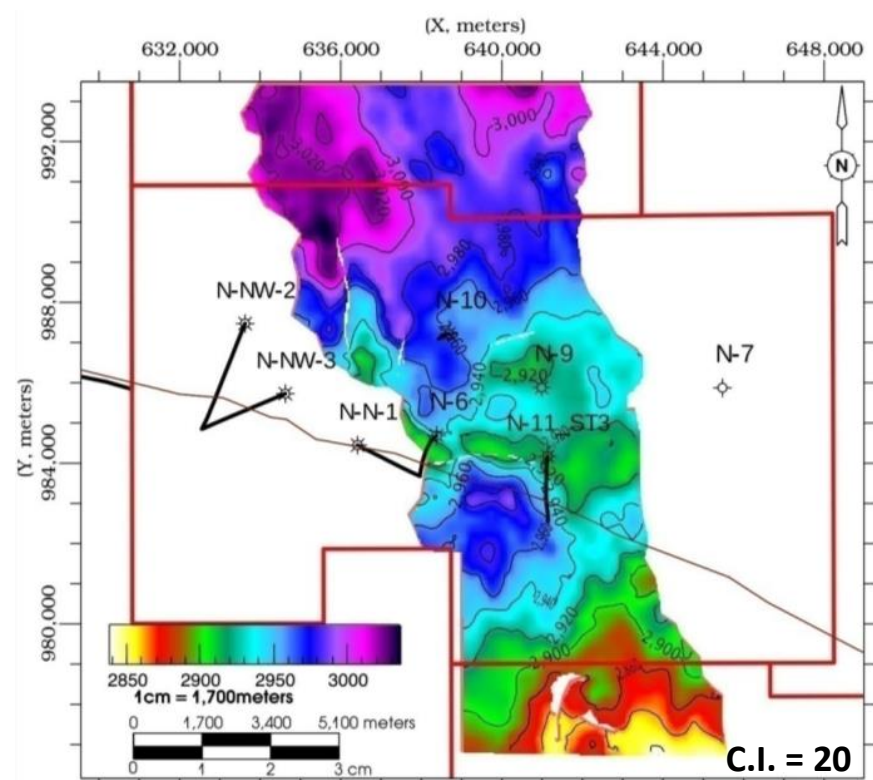

Fig. 8a: Level-3 Time Structural Contour Map.
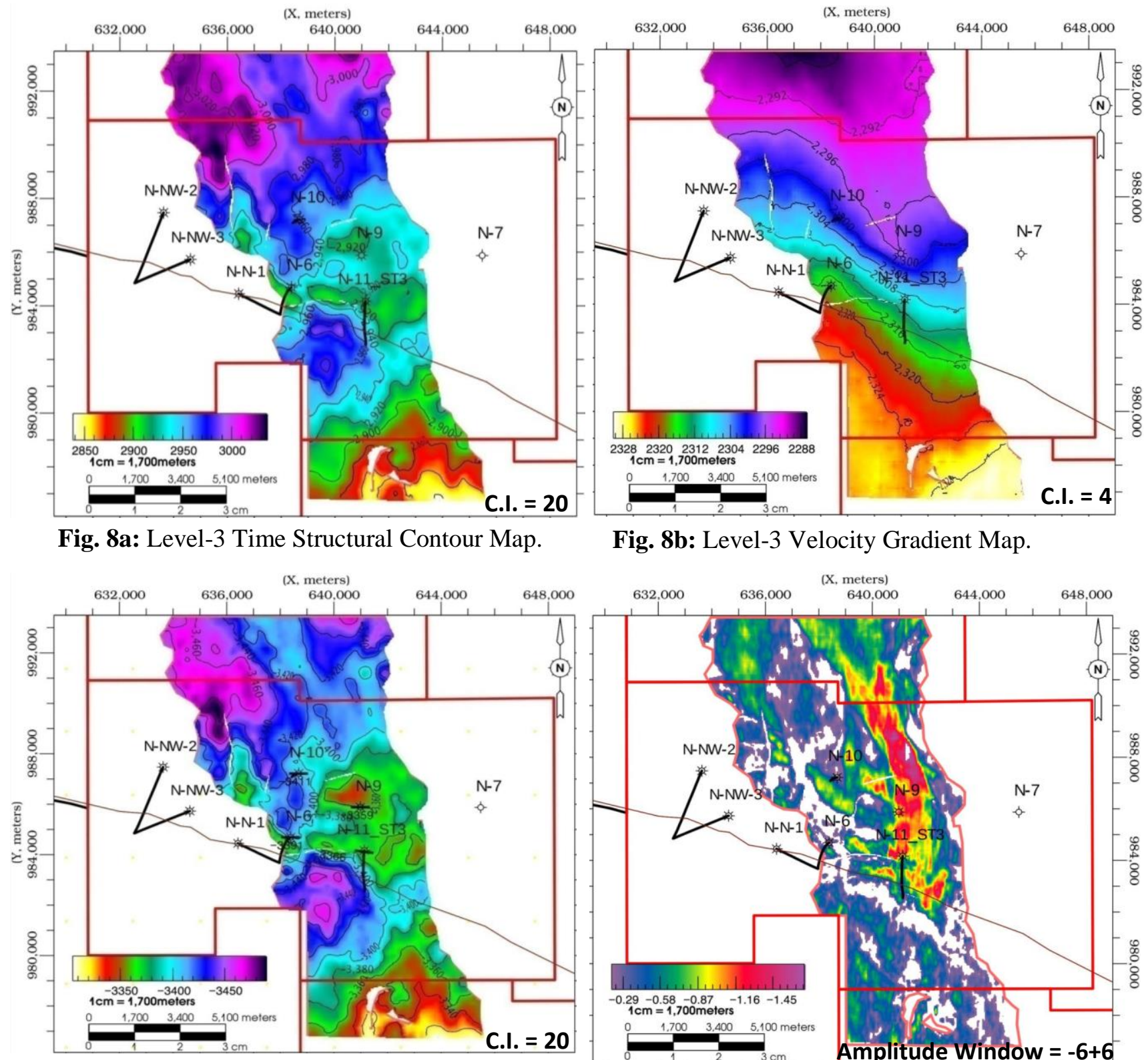

Fig. 8b: Level-3 Velocity Gradient Map.

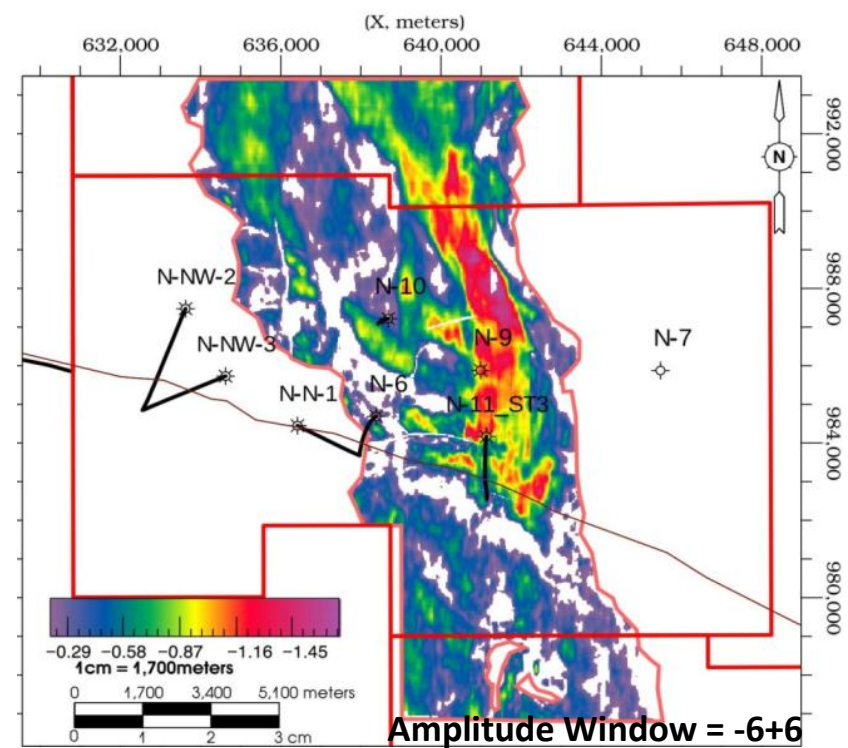

Fig. 8c: Level-3 Depth Structural Contour Map.

Fig. 8d: Level-3 Full Stack Amplitude Map. 


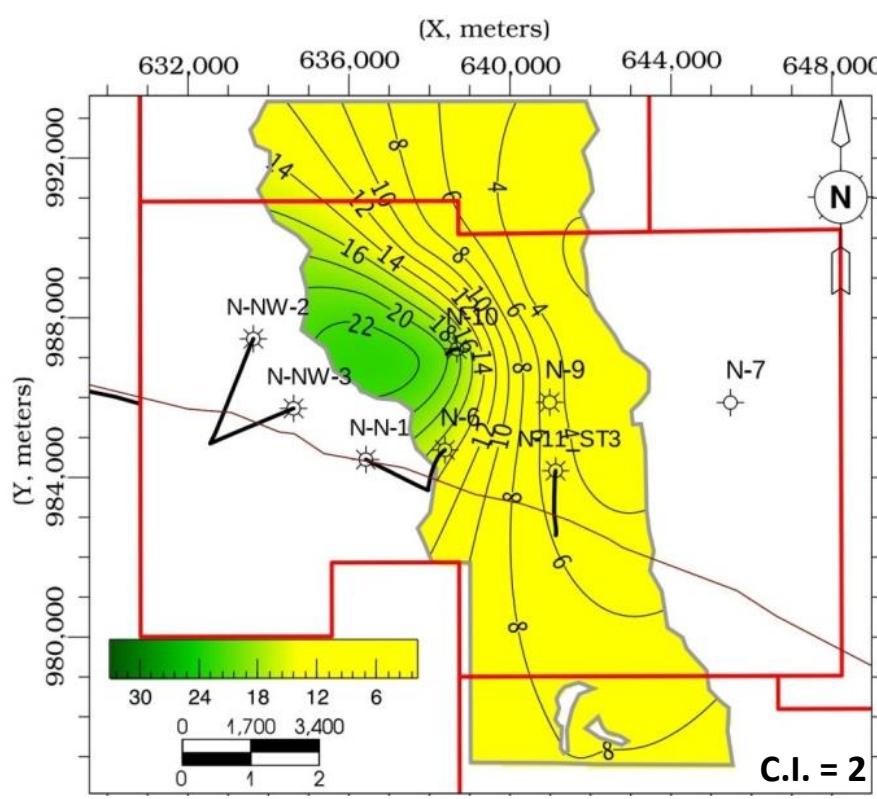

Fig. 8e: Level-3 Shale Content Map (\%).

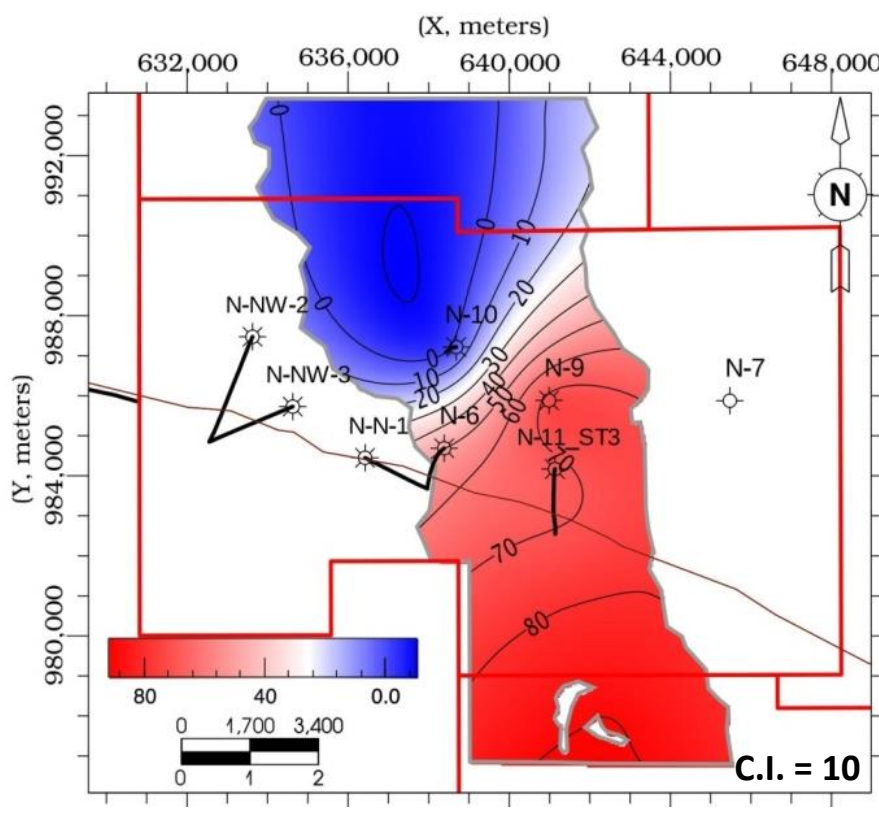

Fig. 8g: Level-3 Hydrocarbon Saturation Map (\%).

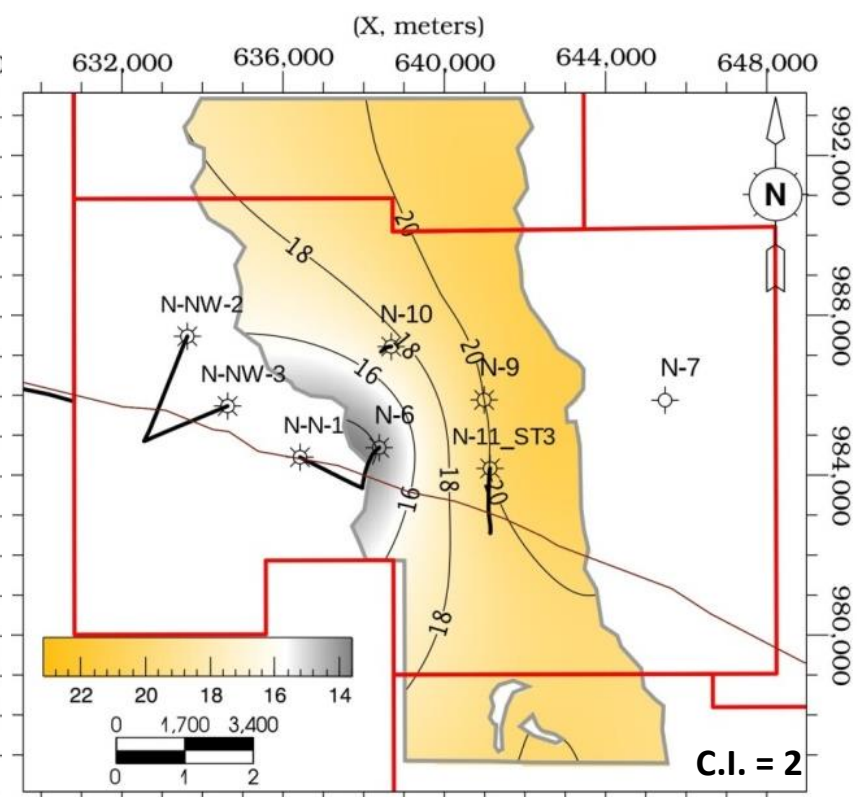

Fig. 8f: Level-3 Effective Porosity Map (\%).

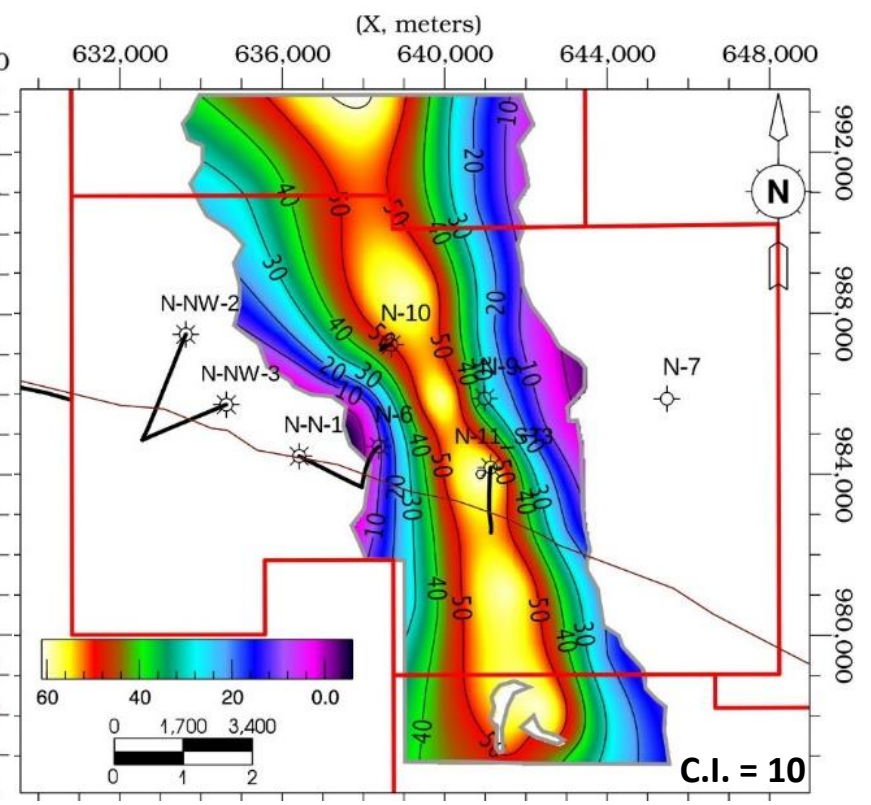

Fig. 8h: Level-3 Reservoir Thickness Map (m). 
التفسير السيزمي و التقييم البتروفيزيائي للخزانين الرئيسيين في تكوين أبو ماضي

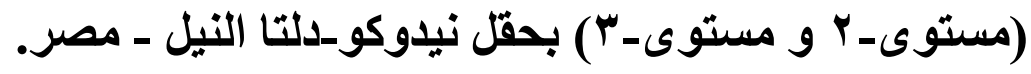

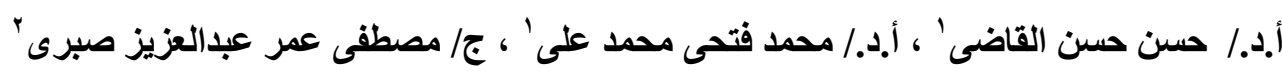

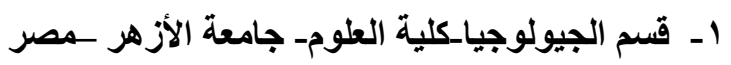

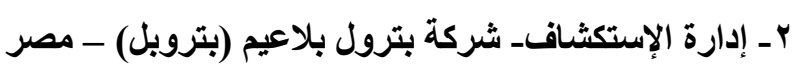

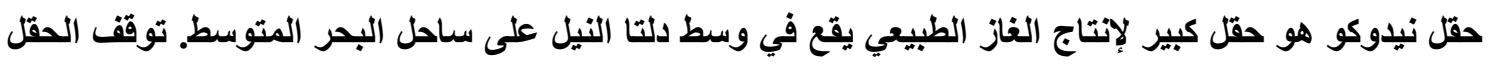

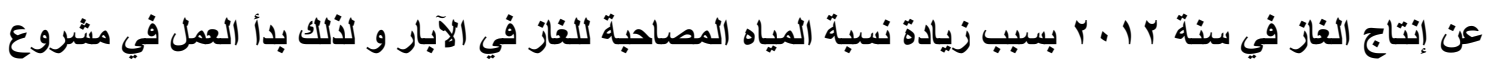

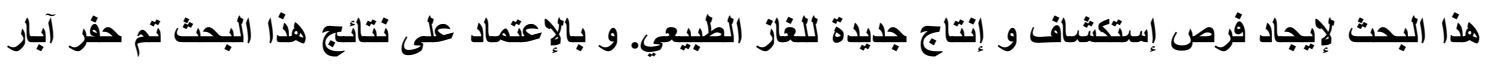

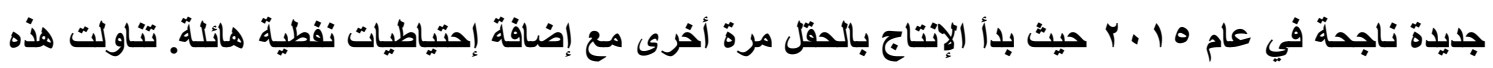

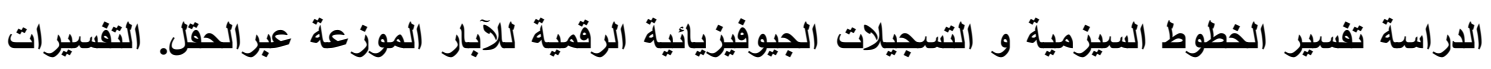

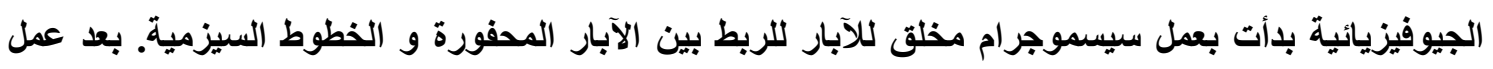

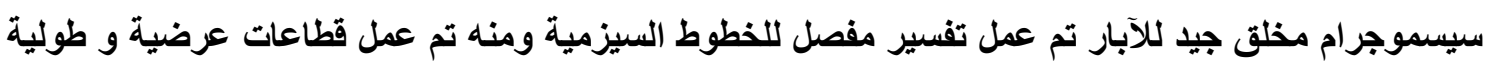

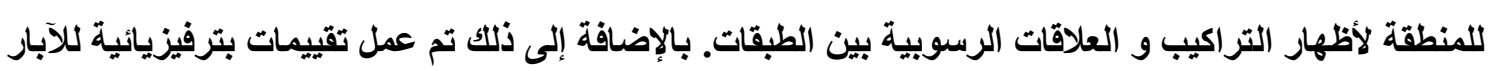

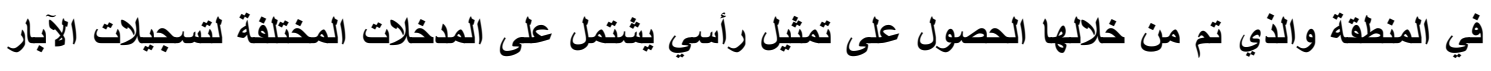

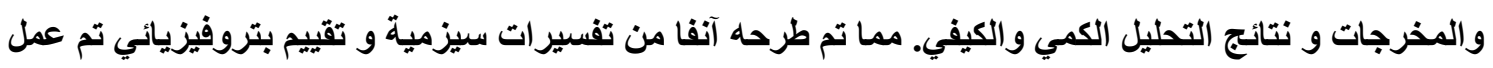

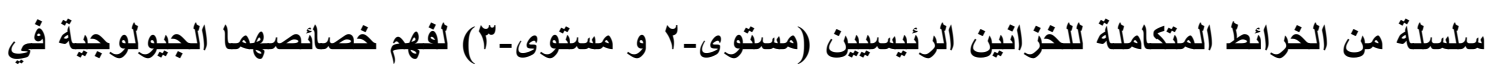

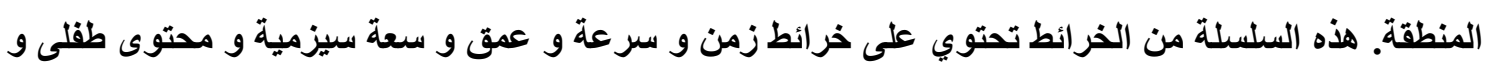

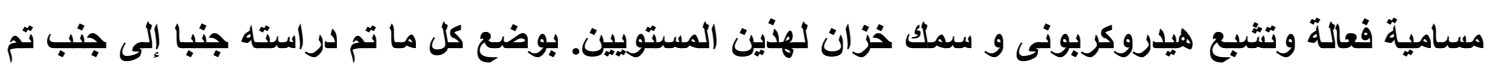

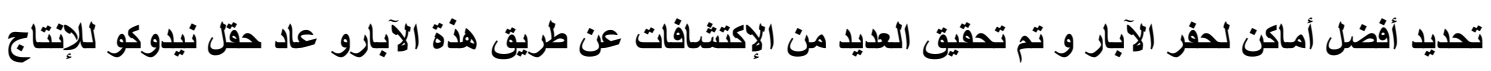

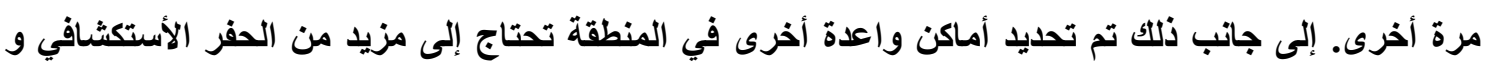
التنموي لما تحتويه من طبقات ذات محتوى مرتفع من البترول. 